\title{
The Relationship between Liver Dysfunction and Arsenic Methylation in Mice
}

\author{
Shugang $\mathrm{Li}^{1}$, Rulin $\mathrm{Ma}^{1}$, Qiang Niu', Shangzhi Xu' ${ }^{1}$, Lijuan Pang', \\ Yusong Ding ${ }^{1}$, Lati Mu ${ }^{1}$, Mingxia Jing ${ }^{1}$, Gangling Feng ${ }^{1}$, Jia Ming Liu ${ }^{1}$, \\ Haixia Wang ${ }^{1}$, Feng $\mathrm{Li}^{2 *}$, Shuxia Guo ${ }^{1 * *}$

\begin{abstract}
'Department of Public Health and Key Laboratory of Xinjiang Endemic and Ethnic Diseases (Ministry of Education) ${ }^{2}$ Department of Pathology and Key Laboratory of Xinjiang Endemic and Ethnic Diseases (Ministry of Education) Shihezi University School of Medicine, Shihezi, Xinjiang 832002, China
\end{abstract}

Received: 22 January 2015

Accepted: 22 March 2015

\begin{abstract}
The different methyl metabolic products of inorganic arsenic lead to various toxicities. Arsenic has been demonstrated to induce hepatotoxicity by oxidative stress. The relationship between hepatic injury and inorganic methylation is not yet known. This study was designed to explore the relationship between arsenic methylation and liver oxidative stress induced by arsenic trioxide (ATO). Forty healthy KM mice were randomly divided into control group (0.9\% saline) and $\mathrm{As}_{2} \mathrm{O}_{3}(1.0 \mathrm{mg} / \mathrm{Kg} /$ day, $2.0 \mathrm{mg} / \mathrm{Kg} /$ day, $4.0 \mathrm{mg} / \mathrm{Kg} /$ day $)$ groups with gastric perfusion for five weeks using high-efficiency liquid chromatography and hydride genesis atomic fluorescence spectroscopy (HPLC-HGAFS). The products of arsenic trioxiode methylating, including trivalent inorganic arsenic $\left(\mathrm{iAs}^{3+}\right)$, pentavalent inorganic arsenic (iAs $\mathrm{s}^{5+}$ ), mono methyl arsenic (MMA), and dimethyl arsenic (DMA) in the liver were determined. The indexes of arsenic methylation, including primary methyl index (PMI) and second methyl index (SMI) were calculated. The level of hepatic function and activity of MDA, GSH, SOD, and TAOC were detected with kits. We found that the remaining arsenic metabolic products in liver significantly increased with the increasing doses of arsenic trioxide and the liver function and oxidative stress deteriorated. Negative correlations were found between MMA\%, PMI and GSH, SOD, and TAOC, while DMA\% and SMI positively correlated with the levels of ALT and AST. PMI and SMI negatively correlated with TAOC, GSH, SOD, ALT, and AST, positively linked with the level of MDA. The present study demonstrates that the hepatotoxicity induced by the arsenic accounts for deteriorating oxidative injury activized by arsenic methylation metabolism, providing additional evidence to suggest a mechanism of arsenic poisoning. Therefore, reducing the process of arsenic methylation may be potentially benefical in treating and - more importantly - preventing arseniasis.
\end{abstract}

Keywords: arsenic trioxide, arsenic methylation, liver, oxidative stress, correlation analysis

*e-mail: lifeng7855@126.com

**e-mail: pge888@sina.com

Authors Shugang Li and Rulin Ma contributed equally to this work. 


\section{Introduction}

Chronic exposure to arsenic (As) through drinking water from natural sources is associated with cancer, cardiovascular disease, diabetes, and developmental and reproductive effects [1-4]. The different metabolic products of inorganic arsenic will lead to different hepatoxicities [5]. The trivalent mono methyl arsenic (MMA III) one of the metabolic products of arsenic metabolism, is regarded as a virulent toxicants $[6,7]$. So the arsenic metabolism process becomes the global focus to be researched widely.

Oxidative injury is one of the important arsenic toxicity mechanisms that can be mediated by excess production of reactive oxygen species (ROS) [8-12]. Furthermore, inorganic arsenic produces toxicity by binding protein thiol groups and non-protein thiols such as glutathione (GSH) [13]. Arsenic also regulates the activity of superoxide dismutase (SOD), glutathione peroxidase (GSH-Px), glutathione reductase (GR), and catalase [14].

Arsenic, a well known exogenous stressor and hepatoxicant $[15,16]$, could create a state of oxidative stress in liver. Some researches showed that different arsenic metabolic products could lead various hepatoxicity in the liver cell lines [17]. While there are no reports on the relationship between the arsenic metabolic methylation process and liver function and oxidative stress, we hypothesize that the levels of arsenic methylation metabolism were linked with the hepatoxicity and oxidative stress in liver.

This study was designed to disclose the relationship among the hepatoxicity of the mice exploring the different doses of arsenic trioxide (ATO), the level of arsenic methylation metabolism, and the degree of oxidative stress. The findings in this study can provide empirical evidence for better understanding the mechanisms of arsenic poisoning.

\section{Materials and Methods}

\section{Chemicals}

Arsenic trioxide (ATO, $\mathrm{As}_{2} \mathrm{O}_{3}$, arsenite) was purchased from Beijing Chemical Reagent Corp. (Beijing, China) and dissolved in $1 \mathrm{~N} \mathrm{NaOH}$ at $0.1 \mathrm{M}$ as a stock solution. Glutathione (GSH), superoxide dismutase (SOD), total antioxidative capacity (T-AOC), malondialdehyde (MDA), bicinchoninic acidprotein, alanine aminotransferase (ALT), and aspartate aminotransferase (AST) assay kits were purchased from Nanjing Jiancheng Bioengineering Institute (Nanjing, China). All other chemicals were of analytical grade and obtained commercially.

\section{Animals and Treatment}

40 healthy Kunming mice (18-22 g, 20 male, 20 female) were obtained from the laboratory center of XinJiang Medical University (Urumqi, China). Throughout the experimental period, mice were housed in well-ventilated cages in a temperature-controlled room at $22-25^{\circ} \mathrm{C}$.
The mice were kept under sterile conditions on a $12 \mathrm{~h}$ light/dark cycle and fed a standard laboratory diet composed of $60 \%$ corn meal, $15 \%$ beans, $10 \%$ bran, $10 \%$ corn oil, $3 \%$ casein, $1 \%$ mineral mixture, and $1 \%$ vitamin mixture. The mice had free access to food and water.

After a two-week acclimation period, the mice were divided based on body weight into four groups: control, and three ATO-treated groups: $1 \mathrm{mg} / \mathrm{Kg} / \mathrm{day}, 2 \mathrm{mg} / \mathrm{Kg} /$ day, and $4 \mathrm{mg} / \mathrm{Kg} /$ day. Each group consisted of 10 mice and all groups were dosed intragastrically for five weeks. The control group received normal saline (NS). A previous report showed that both $1 \mathrm{mg} / \mathrm{Kg} /$ day and $5 \mathrm{mg} / \mathrm{kg}$ ATO induced liver injury but did not affect survival in mice [18, 19]. Therefore, the ATO group received $1 \mathrm{mg} / \mathrm{Kg} / \mathrm{day}, 2$ $\mathrm{mg} / \mathrm{Kg} /$ day, and $4 \mathrm{mg} / \mathrm{kg} /$ day ATO in our study.

\section{Preparation of Plasma and Liver Function Parameters}

The blood samples were collected into evacuated tubes containing heparinic solution as anticoagulant and then centrifuged at $3,000 \mathrm{~g}$ for $10 \mathrm{~min}$. The activities of alanine aminotransferase (ALT) and aspartate aminotransferase (AST) were detected using commercial kits.

\section{Collection of Liver Tissues and Liver Somatic Index}

At the end of the treatment period, the mice were sacrificed by cervical dislocation and the body weight of each mouse was recorded. After washing and drying with filter paper, the livers were collected and weighed to the nearest milligram on an electronic balance (Shimadzu Model BL$220 \mathrm{H}$, Tokyo, Japan). The relative liver weight was calculated according to the following formula:

$$
\text { Index weight }=\text { liver weight/body weight } \times 100 \%
$$

\section{Histopathological Examination of Liver Tissue}

After weighing, the liver was divided into three sections. One section was used for preparation of tissue homogenates and one section was frozen in liquid nitrogen and stored at $-80^{\circ} \mathrm{C}$ for total RNA extraction and immunoblot analysis. The remaining section was fixed in $10 \%$ neutral formalin for at least $24 \mathrm{~h}$, dehydrated in different grades of alcohol, and embedded in paraffin. Sections $(5 \mu \mathrm{m})$ of fixed liver tissue were cut using a rotary microtome. The sections were processed and passed through a graded alcohol series, dyed with hematoxylin and eosin, cleared in xylene, and inspected microscopically as described previously [20].

\section{Preparation of Liver Homogenates}

Liver tissues were placed in lysis buffer $(\mathrm{m} / \mathrm{v}=1: 9)$ containing $20 \mathrm{mM}$ Tris (pH 7.5), $150 \mathrm{mM} \mathrm{NaCl}, 1 \%$ Triton X100 , and the protein inhibitors sodium pyrophosphate, 
$\beta$-glycerophosphate, ethyleneediaminetetraacetic acid, $\mathrm{Na}_{3} \mathrm{VO}_{4}$, and leupeptin (Beyotime Biotechnology, Shanghai, China). The liver tissues were then homogenized with a tissue lyser (Qiagen, Valencia, CA, USA). After the homogenate was centrifuged at $2,500 \times \mathrm{g}$ for $10 \mathrm{~min}$ at $4^{\circ} \mathrm{C}$, the supernatant was collected to determine the activity of ALT, AST, SOD, T-AOC, and the content of GSH and MDA.

\section{Measurement of Lipid Peroxidation}

MDA, a marker of lipid peroxidation, was measured with a commercial kit following the manufacturer's instructions. Briefly, the samples were treated with thiobarbituric acid, which produces a red compound with an absorption maximum at $532 \mathrm{~nm}$ in the presence of MDA. The concentration of MDA was calculated by comparing the absorbance to that produced by the standard - 1,1,3,3-tetraethoxypropane.

\section{Measurement of Antioxidant Enzyme Assay}

GSH specifically deoxidizes dithio-bis-nitrobenzoic acid to form a yellow product, 2-nitro-5-SH-benzoic acid, which can be measured by colorimetry at $532 \mathrm{~nm}$. SOD activity was measured using a tetrazolium salt for detection of superoxide radicals generated by xanthine oxidase and hypoxanthine. One unit of SOD is defined as the amount of enzyme needed to exhibit 50\% dismutation of the superoxide radical at $37^{\circ} \mathrm{C}$. The reaction product was measured at $450 \mathrm{~nm}$. T-AOC in the tissue was measured using a commercial analysis kit that used antioxidants in the samples to reduce $\mathrm{Fe}^{3+}$ to $\mathrm{Fe}^{2+}$, which was then chelated with porphyrin to produce a purple complex that was quantified by measuring the absorbance at $550 \mathrm{~nm}$. The T-AOC of the samples was determined by comparison with the control standard. Results were normalized to the total amount of protein as measured by bicinchoninic acid protein assay.

\section{Analysis of Arsenic Species in Liver}

Arsenic species in mice livers were determined by hydride genesis atomic fluorescence spectroscopy (HPLCHGAFS) [21, 22]. Briefly, 10\% (w/v) liver homogenates prepared in deionized water were microwave-digested in ultrapure phosphoric acid overnight [23]. Aliquots of the digestates $(50 \mu \mathrm{l}$ each) were reduced with $2 \%$ cysteine (EMD Chemicals Inc., NJ, US), and analyzed for As species. The concentrations of total inorganic arsenic $\left(\mathrm{iAs}=\mathrm{i} A s^{\mathrm{II}}+\mathrm{iAs} s^{\mathrm{V}}\right)$, monomethylated arsenic (MMA), and dimethylated arsenic (DMA) were calculated using calibration curves prepared for standard iAsV, MMA, and DMAV (0.5-2.0 ppb) reduced with $2 \%$ cysteine. The following indices were calculated to evaluate the levels of arsenic methylation:

$$
\begin{gathered}
\mathrm{iAs} \%=\left(\mathrm{iAs} s^{\mathrm{II}}+\mathrm{iAs}^{\mathrm{V}}\right) / \mathrm{TAs} \times 100 \%, \\
\mathrm{MMA} \%=\mathrm{MMA} / \mathrm{TAs} \times 100 \%, \\
\text { DMA } \%=\mathrm{DMA} / \mathrm{TAs} \times 100 \%,
\end{gathered}
$$

Primary methylation index $(\mathrm{PMI})=(\mathrm{DMA}+\mathrm{MMA}) / \mathrm{TAs}$, Secondary methylated index $(\mathrm{SMI})=\mathrm{DMA} /(\mathrm{DMA}+\mathrm{MMA})$.

\section{Statistical Analysis}

The results were expressed as the mean \pm standard deviation. ANOVA was used to detect the differences among the low-, medium-, and high-dose ATO groups, followed by Bonferroni's multiple comparison test to determine whether the differences were significant. The Spearman collation analysis was used to evaluate the relationship between arsenic methylation levels and liver functions and oxidative stress. The data were analyzed using SPSS software for Windows version 15.0 (SPSS Inc., Chicago, IL, USA), and a result of $\mathrm{P}<0.05$ was considered to be statistically significant.

\section{Ethics Statement}

This study was approved by THE Institutional Ethics Review Board at the First Affiliated Hospital, Shihezi University School of Medicine. The mice were well bred during the period of the experiment, at the end of which they were sacrificed by cervical dislocation to reduce the suffering as quickly as possible.

\section{Results}

Remaining Total Arsenic and Methylated Products Elevated with Increasing Doses of ATO

The concentration of different specific arsenic and total arsenic were significantly higher than that of the control group ( $\mathrm{P}<0.001$ respectively). With the increasing doses of arsenic, the concentrations of specific arsenic showed the increasing trend significantly $(\mathrm{P}<0.001$ respectively). In addition, the content of DMA was obviously higher than other specific arsenics in each group $(\mathrm{P}<0.001$ respectively, Table 1).

\section{The Level of Arsenic Methylation Improved with Increasing Does of ATO}

The level of $\mathrm{iAs} \%$ and MMA $\%$ improved significantly with the increasing doses of ATO $(\mathrm{P}<0.001$ respectively). $\mathrm{DMA} \%$ of ATO-treated groups were significantly higher than that of control group ( $\mathrm{P}<0.001$, respectively). Among the ATO-treated groups, DMA\% of the middle- and highdose groups were significantly higher than of the low-dose group $(\mathrm{P}<0.001)$. PMI and SMI both rose significantly with the increasing ATO doses, and the high-dose group was significantly higher than the low-dose group $(\mathrm{P}<0.001$ respectively; Table 2).

\section{Liver Function Deterioration with Increasing Doses of ATO}

The final body weights of ATO treatment groups were significantly lower than that of control $(\mathrm{P}<0.001$ respectively), while the level of liver weight, liver index, ALT, and 
Table 1. The remains of total arsenic and methylated products in liver treated with ATO (mean $\pm \mathrm{SD}, \mathrm{n}=10, \mathrm{ng} / \mathrm{g}$ ).

\begin{tabular}{|l|c|c|c|c|c|}
\hline \multicolumn{1}{|c|}{ Group } & \multicolumn{1}{c|}{$\mathrm{iAs}^{3+}$} & $\mathrm{iAs}^{5+}$ & MMA & DMA & TAs \\
\hline Control & $0.00 \pm 0.00$ & $0.00 \pm 0.00$ & $4.73 \pm 2.02$ & $16.62 \pm 3.91$ & $21.35 \pm 4.29$ \\
\hline $1 \mathrm{mg} / \mathrm{Kg}$ & $1.57 \pm 0.45^{*}$ & $1.91 \pm 0.57^{*}$ & $4.69 \pm 1.63$ & $232.63 \pm 40.20^{* *}$ & $240.80 \pm 42.00^{*}$ \\
\hline $2 \mathrm{mg} / \mathrm{Kg}$ & $11.25 \pm 4.04^{* *}$ & $9.66 \pm 3.46^{* *}$ & $13.04 \pm 4.41^{* *}$ & $466.35 \pm 176.96^{* *}$ & $500.30 \pm 187.42^{* *}$ \\
\hline $4 \mathrm{mg} / \mathrm{Kg}$ & $23.41 \pm 4.99^{* *} \Delta$ & $9.84 \pm 1.87^{* *}$ & $35.43 \pm 10.50^{* *} \Delta$ & $967.73 \pm 182.20^{* *} \Delta$ & $1036.40 \pm 193.74^{* * \Delta}$ \\
\hline$F$ & 112.499 & 66.809 & 100.783 & 61.762 & 102.788 \\
\hline$P$ & $<0.001$ & $<0.001$ & $<0.001$ & $<0.001$ & $<0.001$ \\
\hline
\end{tabular}

*indicates that $\mathrm{p}<0.001$ compared with control group, ${ }^{*}$ represents $\mathrm{p}<0.001$ compared with the low-dose $(1 \mathrm{mg} / \mathrm{Kg})$ group, $\Delta$ depicts $\mathrm{p}<0.001$ compared with the low-dose $(2 \mathrm{mg} / \mathrm{Kg})$ group.

Table 2. The levels of arsenic methylation in liver with doses of ATO treatment (mean $\pm \mathrm{SD}, \mathrm{n}=10$ ).

\begin{tabular}{|l|c|c|c|c|c|}
\hline \multicolumn{1}{|c|}{ Group } & iAs $\%$ & MMA $\%$ & DMA $\%$ & PMI & SMI \\
\hline Control & $0.00 \pm 0.00$ & $22.21 \pm 8.40$ & $77.79 \pm 8.40$ & $1.0000 \pm 0.0000$ & $0.7779 \pm 0.0840$ \\
\hline $1 \mathrm{mg} / \mathrm{Kg}$ & $1.45 \pm 0.32^{*}$ & $1.91 \pm 0.46^{*}$ & $93.37 \pm 0.82^{*}$ & $0.9680 \pm 0.0024^{*}$ & $0.9645 \pm 0.0082^{*}$ \\
\hline $2 \mathrm{mg} / \mathrm{Kg}$ & $4.20 \pm 0.20^{* *}$ & $2.71 \pm 0.92^{* *}$ & $93.09 \pm 1.02^{*}$ & $0.9580 \pm 0.0020^{*}$ & $0.9717 \pm 0.0097^{*}$ \\
\hline $4 \mathrm{mg} / \mathrm{Kg}$ & $3.20 \pm 0.24^{* *} \Delta$ & $3.43 \pm 0.79^{* *} \Delta$ & $96.65 \pm 0.64^{* *}$ & $0.9856 \pm 0.0032^{* *}$ & $0.9806 \pm 0.0047^{* *}$ \\
\hline$F$ & 703.153 & 52.991 & 39.255 & 703.153 & 52.433 \\
\hline$P$ & $<0.001$ & $<0.001$ & $<0.001$ & $<0.001$ & $<0.001$ \\
\hline
\end{tabular}

*indicates $\mathrm{p}<0.001$ compared with control group, "indicates $\mathrm{p}<0.001$ compared with the low-dose $(1 \mathrm{mg} / \mathrm{Kg})$ group, $\triangle$ indicates $\mathrm{p}<0.001$ compared with the low-dose $(2 \mathrm{mg} / \mathrm{Kg})$ group.

Table 3. The effect on the level of liver function treated with ATO (mean $\pm S D, n=10)$.

\begin{tabular}{|l|c|c|c|c|c|}
\hline \multicolumn{1}{|c|}{ Group } & Body weight $(\mathrm{g})$ & Liver weight $(\mathrm{g})$ & Liver index (\%) & ALT (U/g prot) & AST (U/g prot) \\
\hline Control & $37.47 \pm 2.26$ & $1.33 \pm 0.19$ & $3.56 \pm 0.62$ & $86.97 \pm 27.85$ & $17.49 \pm 6.75$ \\
\hline $1 \mathrm{mg} / \mathrm{Kg}$ & $32.34 \pm 2.28^{*}$ & $2.23 \pm 0.25^{*}$ & $6.95 \pm 1.12^{*}$ & $99.18 \pm 26.85^{*}$ & $20.88 \pm 5.86^{*}$ \\
\hline $2 \mathrm{mg} / \mathrm{Kg}$ & $29.03 \pm 1.85^{*}$ & $2.77 \pm 0.17^{*}$ & $9.59 \pm 0.80^{*}$ & $101.92 \pm 47.42^{*}$ & $27.89 \pm 6.41^{* *}$ \\
\hline $4 \mathrm{mg} / \mathrm{Kg}$ & $26.80 \pm 1.47^{* *} \Delta$ & $3.22 \pm 0.17^{* *}$ & $12.05 \pm 0.86^{* *}$ & $132.57 \pm 39.63^{* *} \Delta$ & $31.32 \pm 5.12^{* * \Delta}$ \\
\hline$F$ & 54.1 & 171.974 & 175.056 & 3.298 & 10.878 \\
\hline$P$ & $<0.001$ & $<0.001$ & $<0.001$ & 0.031 & $<0.001$ \\
\hline
\end{tabular}

*indicates $\mathrm{p}<0.001$ compared with control group, "indicates $\mathrm{p}<0.001$ compared with the low-dose $(1 \mathrm{mg} / \mathrm{Kg})$ group, $\triangle$ indicates $\mathrm{p}<0.001$ compared with the low-dose $(2 \mathrm{mg} / \mathrm{Kg})$ group.

AST of ATO treatment groups were significantly higher than that of control $(\mathrm{P}<0.001$, respectively). With the increasing doses of ATO, level of liver index, ALT, and AST elevated obviously ( $\mathrm{p}<0.001$, respectively; Table 3 ).

To confirm the liver damage induced by ATO, we examined liver histology in tissues from the treated mice. The high doses of the ATO group resulted in an indistinct hepatocyte boundary, disappearance of the cell membrane, and cytoplasmic disintegration, in addition to the intracytoplasmic accumulation of lipid droplets and degeneration of hepatocytes (Fig. 1D). The middle (Fig. 1C) and low (Fig. 1B) does of ATO-treated groups showed the partial liver damage.
The Degree of Oxidative Injury in Liver

Deteriorated with Increasing Doses of ATO

We found that the concentrations of MDA of ATO groups were significantly higher than that of control group $(\mathrm{P}<0.001$, respectively), while the levels of GSH, SOD, and TAOC were lower $(\mathrm{P}<0.001$, respectively). The level of oxidative damage of the high-dose ATO treatment group was higher than the low-dose group $(\mathrm{P}<0.001$, respectively). With the increased doses of ATO, the degree of oxidative damage deteriorated significantly, and the ability of anti-oxidative damage declined $(\mathrm{P}<0.001$, respectively; Table 4). 
The Level of Arsenic Methylation Positively Correlated with the Degree of Oxidative Injury

The relationship between oxidative stress in liver (including MDA, GSH, SOD, TAOC) and arsenic methylation level (PMI, SMI) was analyzed by Spearman correlation analysis stratified with ATO doses. In the low-dose group, PMI was significantly negative related to TAOC $(r=-0.855$, $\mathrm{P}=0.002$ ), SMI was significantly related negatively with the level of $\mathrm{GSH}$ and $\mathrm{SOD}\left(\mathrm{r}_{\mathrm{GSH}}=-0.709, \mathrm{P}_{\mathrm{GSH}}=0.022\right.$, $\left.\mathrm{r}_{\mathrm{SOD}}=-0.782, \mathrm{P}_{\mathrm{SOD}}=0.008\right)$. In the middle dose group, PMI and SMI were both significantly related positively with the level of MDA ( $\mathrm{P}<0.005$, respectively). In the high-dose group, we also found a positive link between PMI and MDA $(\mathrm{P}<0.05)$, and the negative relationship between PMI, SMI, GSH, and SOD ( $\mathrm{P}<0.05$, respectively; Table 5).

We divided PMI and SMI into four groups using quartile points with merging all the data. There was a significant correlative trend between oxidative stress and PMI and SMI, representing the process of arsenic, similar to what we found in each dose group (Figs. 2, 3).
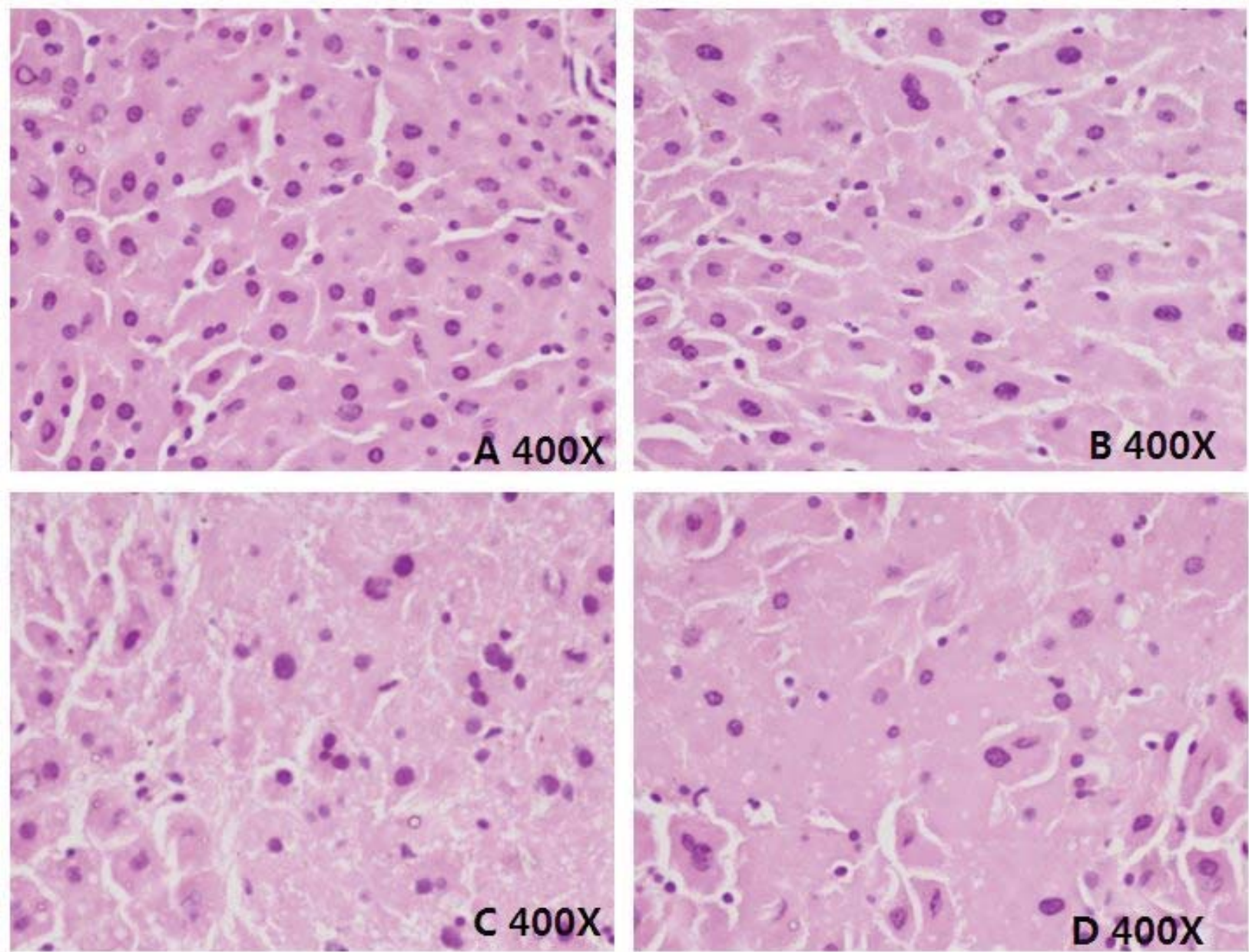

Fig. 1. Morphological changes in mouse liver after ATO treatment. Control group showed normal structure of the hepatic cord, hepatic sinusoid, and hepatocytes (Fig. 1A). Indicators of hepatocyte poisoning were found in the ATO (1 mg/Kg/day) treatment group, such as unclear boundary of hepatocytes, disappearance of the cell membrane, narrow Hepatic sinus, wide hepatic cord, and small amount of cavity bubbles (Fig. 1B). Comparing with ATO (1 mg/Kg/day) group, the middle dose $(2 \mathrm{mg} / \mathrm{Kg} /$ day) group showed unclear boundary of hepatocytes, disappearance of the cell membrane, obviously narrow Hepatic sinus, significantly wide hepatic cord, and amount of cavity bubbles (Fig. 1C). The high dose ( $2 \mathrm{mg} / \mathrm{Kg} /$ day) group indicated the disappearance of hepatic cell nucleus (Fig. 1D). 
Table 4. The effect on the levels of oxidative stress treated with ATO (mean $\pm \mathrm{SD}, \mathrm{n}=10$ ).

\begin{tabular}{|l|c|c|c|c|}
\hline \multicolumn{1}{|c|}{ Group } & MDA (nmol/mg prot) & GSH $(\mu \mathrm{mol} / \mathrm{g}$ prot $)$ & SOD $(\mathrm{U} / \mathrm{g}$ prot $)$ & TAOC (U/g prot) \\
\hline Control & $31.13 \pm 14.99$ & $359.00 \pm 60.39$ & $19.12 \pm 5.60$ & $11.33 \pm 2.00$ \\
\hline $1 \mathrm{mg} / \mathrm{Kg}$ & $82.98 \pm 22.87^{*}$ & $148.49 \pm 43.45^{*}$ & $21.42 \pm 4.24^{*}$ & $7.38 \pm 1.74^{*}$ \\
\hline $2 \mathrm{mg} / \mathrm{Kg}$ & $112.29 \pm 23.21^{* *}$ & $105.13 \pm 33.49^{* *}$ & $23.39 \pm 3.63^{*}$ & $4.82 \pm 2.01^{*}$ \\
\hline $4 \mathrm{mg} / \mathrm{Kg}$ & $169.36 \pm 11.14^{* *} \Delta$ & $52.51 \pm 26.65^{* *} \Delta$ & $24.46 \pm 3.42^{* *}$ & $2.72 \pm 1.13^{* *} \Delta$ \\
\hline$F$ & 94.435 & 97.964 & 2.971 & 44.533 \\
\hline$P$ & $<0.001$ & $<0.001$ & 0.045 & $<0.001$ \\
\hline
\end{tabular}

*indicates $\mathrm{p}<0.001$ compared with control group, ${ }^{*}$ represents $\mathrm{p}<0.001$ compared with the low-dose $(1 \mathrm{mg} / \mathrm{Kg})$ group, $\triangle$ depicts $\mathrm{p}<0.001$ compared with the low-dose $(2 \mathrm{mg} / \mathrm{Kg})$ group.

by arsenic methylation metabolism, providing additional evidence to suggest a mechanism that triggers arsenic poisoning. The Kuitun district (approximately 4,000 km from Beijing) next to Shihezi city (where our university is located) is the location of the first reported case of arsenic poisoning in inner China in 1980. This study provides a potential mechanism of hepototoxicity induced by arsenic, which may be useful to prevent and control local arsenic poisoning.

Our study shows that physiological function and biological toxicity effect of the elements were closely related with its specification [24]. The toxicity of MMA(III), as one of the arsenic metabolic products is more poisonous than trivalent inorganic arsenic, and DMA was found to be obviously carcinogenic [25]. This study about the arsenic methylation metabolism helps to elucidate the function of the arsenic methaylation in arsenic poisoning.

Liver is the important organ for arsenic metabolism [26]. The concentration in liver is significantly higher than other organs [27]. Our study found that the concentration of specific arsenic in mice liver increased obviously with ATO treatment, and DMA occupied most proportions. It reminds us that trivalent inorganic arsenic easily distributed and accumulated in the liver through blood currency. The arsenic metabolism process is also carried out in liver. In addition, the concentrations and percentages of MMA and DMA were significantly increased. Simultaneously, the levels of PMI and SMI were also increased. PMI and SMI
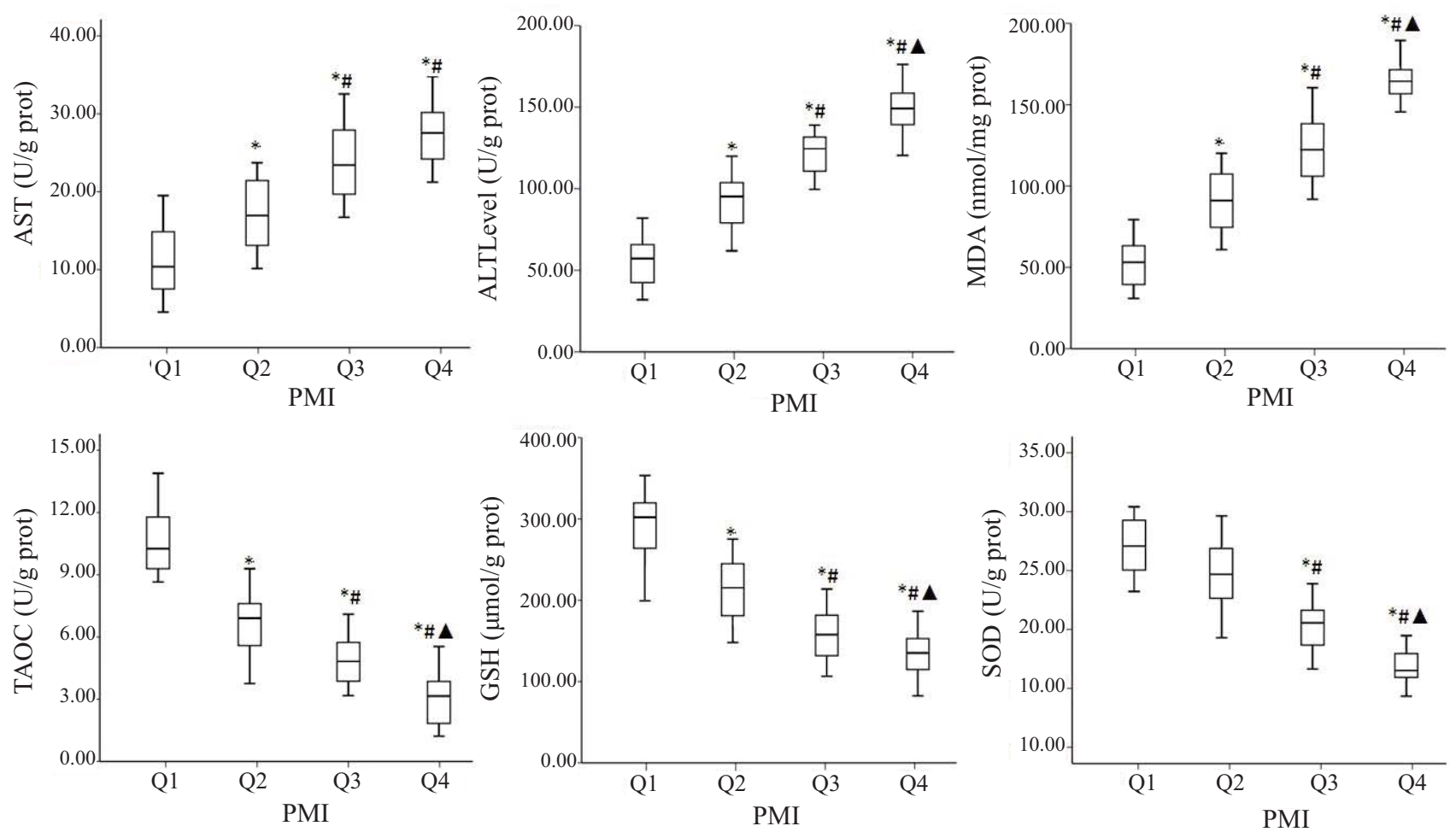

Fig. 2. The effect of arsenic methylation on liver function and oxidative stress. The level of PMI was divided into four groups according to quartile cut-points. With the increasing PMI, the level of liver function (ALT, AST) deteriorated significantly and the anti-oxidative ability (TAOC, GSH, SOD) decreased simultaneously. Q represents the quartile points values of PMI. Q1, Q2, Q3, and Q4 represent $25 \%, 50 \%, 75 \%$, and $100 \%$ point value of PMI. *indicates $\mathrm{p}<0.001$ vs $\mathrm{Q} 1$ group. \# represents $\mathrm{p}<0.001$ vs $\mathrm{Q} 2$ group. $\boldsymbol{\Delta}$ depicts $\mathrm{p}<0.001$ vs Q3 group. 
Table 5. Arsenic methylation level related to oxidative stress.

\begin{tabular}{|c|c|c|c|c|c|c|}
\hline Group & Menthylation indexes & Correlation coefficient & MDA & GSH & SOD & TAOC \\
\hline \multirow{4}{*}{$1 \mathrm{mg} / \mathrm{Kg}$} & \multirow{2}{*}{ PMI } & $r$ & 0.964 & -0.564 & -0.030 & -0.855 \\
\hline & & $P$ & 0.000 & 0.090 & 0.934 & 0.002 \\
\hline & \multirow{2}{*}{ SMI } & $r$ & 0.201 & -0.709 & -0.782 & -0.346 \\
\hline & & $P$ & 0.580 & 0.022 & 0.008 & 0.328 \\
\hline \multirow{4}{*}{$2 \mathrm{mg} / \mathrm{Kg}$} & \multirow{2}{*}{ PMI } & $r$ & 0.720 & -0.806 & -0.770 & -0.358 \\
\hline & & $P$ & 0.019 & 0.005 & 0.009 & 0.310 \\
\hline & \multirow{2}{*}{ SMI } & $r$ & 0.817 & -0.855 & -0.770 & -0.527 \\
\hline & & $P$ & 0.004 & 0.002 & 0.009 & 0.117 \\
\hline \multirow{4}{*}{$4 \mathrm{mg} / \mathrm{Kg}$} & \multirow{2}{*}{ PMI } & $r$ & 0.902 & -0.153 & -0.067 & -0.779 \\
\hline & & $P$ & 0.000 & 0.672 & 0.853 & 0.008 \\
\hline & \multirow{2}{*}{ SMI } & $r$ & 0.042 & -0.952 & -0.564 & -0.139 \\
\hline & & $P$ & 0.907 & 0.000 & 0.090 & 0.701 \\
\hline
\end{tabular}

Bold means correlation coefficients which were statistically significant.

reflect that the ability of arsenic's first methylation step from ingonic arsenic to MMA, and the second period from MMA to DMA. This study elucidated that the ability of arsenic methylation in liver is enhanced with increased doses of ATO. Similar results also have been reported by $\mathrm{Wu}[25]$.

Liver is one of the important target organs of arsenic [28]. Our results showed that the levels of MDA in ATO treatment groups was higher than control, while the levels of GSH, SOD, and TAOC were lower, and the oxidative damage deteriorated with the increasing dose of ATO. MDA is the end product of lipid peroxidation reaction between free radicals and lipids [29]. Our results illustrate that the lipid peroxidation reaction was induced by arsenic, after which it was taken in. The activity of SOD and GSH could reflect the ability of eradicating free radicals [30, 31], and TAOC was the gross anti-oxidative element including macromolecular, micromolecular, and enzymes [32-34].
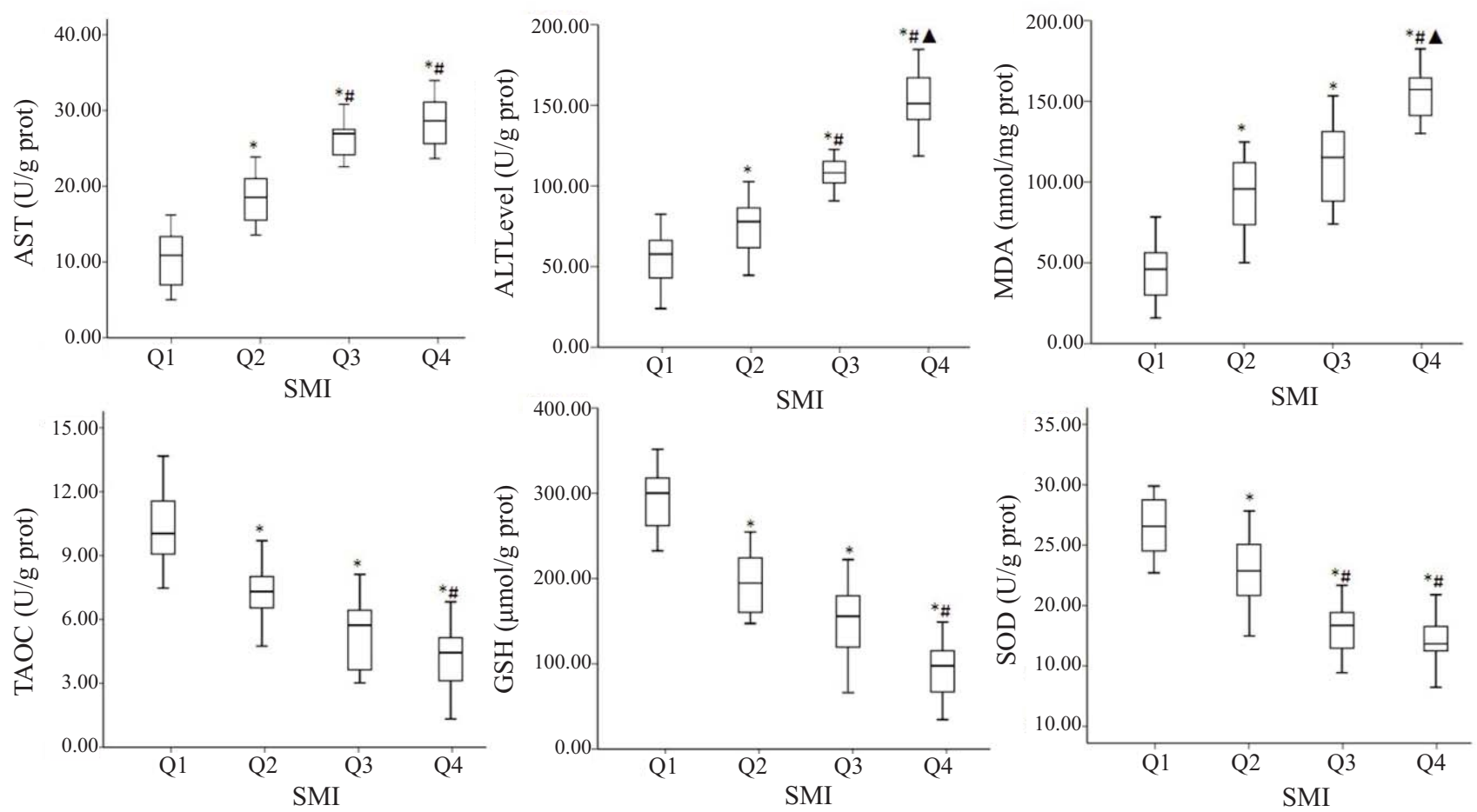

Fig. 3. The effect of arsenic methylation on liver function and oxidative stress. The level of SMI was divided into four groups according to quartile cut-points. With increasing SMI, the level of liver function (ALT, AST) deteriorated significantly, the anti-oxidative ability (TAOC, GSH, SOD) decreased simultaneously. Q represents the quartile point values of SMI. Q1, Q2, Q3, and Q4 represent 25\%, 50\%, $75 \%$, and $100 \%$ point value of SMI. *indicates $\mathrm{p}<0.001$ vs $\mathrm{Q} 1$ group. \# represents $\mathrm{p}<0.001$ vs $\mathrm{Q} 2$ group. $\boldsymbol{\Delta}$ depicts $\mathrm{p}<0.001$ vs $\mathrm{Q} 3$ group. 
Table 6. Arsenic methylation level correlated with liver function.

\begin{tabular}{|c|c|c|c|c|c|c|}
\hline Group & Liver function & Correlation coefficient & MMA $\%$ & DMA\% $\%$ & PMI & SMI \\
\hline \multirow{4}{*}{$1 \mathrm{mg} / \mathrm{Kg}$} & \multirow{2}{*}{ ALT } & $r$ & -0.667 & 0.742 & 0.525 & 0.672 \\
\hline & & $P$ & 0.005 & 0.014 & 0.119 & 0.033 \\
\hline & \multirow{2}{*}{ AST } & $r$ & -0.649 & 0.557 & 0.18 & 0.649 \\
\hline & & $P$ & 0.042 & 0.095 & 0.618 & 0.041 \\
\hline \multirow{4}{*}{$2 \mathrm{mg} / \mathrm{Kg}$} & \multirow{2}{*}{ ALT } & $r$ & -0.578 & 0.696 & 0.898 & 0.580 \\
\hline & & $P$ & 0.080 & 0.025 & $<0.001$ & 0.079 \\
\hline & \multirow{2}{*}{ AST } & $r$ & -0.069 & 0.681 & 0.656 & 0.613 \\
\hline & & $P$ & 0.061 & 0.030 & 0.039 & 0.059 \\
\hline \multirow{4}{*}{$4 \mathrm{mg} / \mathrm{Kg}$} & \multirow{2}{*}{ ALT } & $r$ & -0.493 & 0.300 & 0.697 & 0.303 \\
\hline & & $P$ & 0.148 & 0.399 & 0.025 & 0.394 \\
\hline & \multirow{2}{*}{ AST } & $r$ & -0.642 & 0.622 & 0.139 & 0.623 \\
\hline & & $P$ & 0.046 & 0.055 & 0.702 & 0.054 \\
\hline
\end{tabular}

Bold means correlation coefficients which were statistically significant.

Our finds showed that exposure to arsenic could lead to an increase of free radicals in liver, which induced lipid peroxidation reaction. The anti-oxidative ability of liver decreased. On the other hand, DMA and GSH could react and produced dimethyl arsine - GSH chelate [35], which also induced the oxidative stress in liver because of more free radicals, including dimethyl arsine peroxides and dimethyl arsine acid [36]. Thirdly, we found an interesting result in that liver damage deteriorated with the increase of ATO treatment, which could be explained by arsenic methylation products inducing the lipid peroxidation reaction; furthermore, the oxidative stress caused a decrease in liver function.

We also found another interesting result in that the levels of PMI and SMI were both positively correlated with MDA, which is negatively related to the activity of GSH and SOD in each ATO dose group. These findings remind us that different abilities of arsenic methlation possibly lead to the variation of oxidative damage. The results implicate that the high ability of arsenic methylation could cause more serious oxidative damage in liver. DMA is the important arsenic methylation products accumulated in liver, while increasing DMA could cause more free radicals, reactive oxygen species including $\mathrm{O}_{2}^{-}, \mathrm{H}_{2} \mathrm{O}_{2}, \mathrm{OH}$, and a special radical - methylated arsenics radical [37], which could induce oxidative liver damage. This study shows a positive relationship between DMA \%, PMI, SMI, and ALT, AST, and anegative link between MMA $\%$ and liver function in different arsenic treatments. MMA is the intermediate in the process from inorganic arsenic to DMA. The increase of MMA reflects the incompletion of arsenic methylation. So it could interpret the relationship between arsenic methylation and hepatoxicity. To some extent, high methylation cause serious hepatoxicity. This is because DMA was the main product of inorganic arsenic methylation, and the increasing level of DMA could cause serious oxidative stress in liver with the accumulation of reactive oxygen, which causes liver swelling, and the liver index, ALT, and AST to increase.

\section{Conclusion}

In summary, the present study demonstrates that the hepatotoxicity induced by arsenic accounts for deteriorating oxidative injury activized by arsenic methylation metabolism, providing additional evidence to suggest the mechanism of arsenic poisoning. Therefore, reducing the process of arsenic methylation may be potentially benefical in treating and, more importantly, preventing arseniasis. The range of ATO doses should be expanded to observe the variation principles of arsenic methylation. The future work should be focused on the molecular mechanism so as to provide more evidence for the relationship between arsenic methylation and liver damage.

\section{Acknowledgements}

The authors are grateful to the Key Laboratory of Xinjiang Endemic and Ethnic Diseases (Ministry of Education), Shihezi University School of Medicine for assistance with this work. This work was supported by grants from Xinjiang Production and Construction Corps (2014BA039) and Shihezi University (RCZX201112).

\section{References}

1. NRC. Arsenic in Drinking Water. Washington, DC: National Academy Press, 1999.

2. ATSDR. Toxicological Profile for Arsenic (Update). Atlanta: Agency for Toxic Substances and Disease Registry, 1999. 
3. ABERNATHY C.O., LIU Y.P., LONGFELLOW D., APOSHIAN H.V., BECK B., FOWLER B., GOYER R., MENZER R., ROSSMAN T., THOMPSON C., WAALKES M. Arsenic: health effects, mechanisms of actions, and research issues. Environ Health Perspect, 107, 593, 1999.

4. SMITH A.H., HOPENHAYN-RICH C., BATES M.N., GOEDEN H.M., HERTZ-PICCIOTTO I., DUGGAN H.M., WOOD R., KOSNETT M.J., SMITH MT. Cancer risks from arsenic in drinking water. Environ Health Perspect. 97, 259, 1992

5. AGUSA T., FUJIHARA J., TAKESHITA H., IWATA H. Individual variations in inorganic arsenic metabolism associated with AS3MT genetic polymorphisms. Int. J. Mol.Sci. 12, 2351, 2011.

6. CONCHA G., NERMELL B., VAHTER M.V. Metabolism of inorganic arsenic in children with chronic high arsenic exposure in Northern Argentina. Environ. Health Perspect. 106, 355, 1998.

7. CURRIER J.M., SVOBODA M., MATOUSEK T., DEDINA J., STYBLO M. Direct analysis and stability of methylated trivalent arsenic metabolites in cells and tissues. Metallomics. 3, 1347, 2011

8. CIRCU M.L., AW T.Y. Reactive oxygen species, cellular redox systems, and apoptosis. Free Radic Biol Med. 48, 749, 2011

9. BATAILlE A.M, MANAUTOU J.E. Nrf2: A Potential Target for New Therapeutics in Liver Disease. Clin Pharmacol Ther. 92, 340, 2012.

10. XU H., LAM S.H., SHEN Y., GONG Z. Genome-Wide Identification of Molecular Pathways and Biomarkers in Response to Arsenic Exposure in Zebrafish Liver. PLoS One 8:e68737, 2013.

11. ALBANO E. Alcohol, oxidative stress and free radical damage. Proc Nutr Soc 65, 278, 2006.

12. VILLACA CHAVES G., PEREIRA S.E., SABOYA C.J., RAMALHO A. Non-alcoholic fatty liver disease and its relationship with the nutritional status of vitamin A in individuals with class III obesity. Obes Surg 18, 378, 2008.

13. ALDABA-MURUATO L.R., MORENO M.G., SHIBAYAMA M., TSUTSUMI V., MURIEL P. Protective effects of allopurinol against acute liver damage and cirrhosis induced by carbon tetrachloride: modulation of NF-kappa B, cytokine production and oxidative stress. Biochim Biophys Acta. 1820, 65, 2012.

14. ZHOU L., YANG Y., TIAN D., WANG Y. Oxidative stressinduced 1, N6-ethenodeoxyadenosine adduct formation contributes to hepatocarcinogenesis. Oncol Rep 29, 875, 2013.

15. ZHANG Q., PI J., WOODS C.G., ANDERSEN M.E. A Systems Biology Perspective on Nrf2-Mediated Antioxidant Response. Toxicol Appl Pharmacol 244, 84, 2010.

16. LI B., LI X., ZHU B., ZHANG X., WANG Y., XU Y., WANG H., HOU Y., ZHENG Q., SUN G. Sodium arsenite induced reactive oxygen species generation, nuclear factor (erythroid-2 related) factor 2 activation, heme oxygenase-1 expression, and glutathione elevation in Chang human hepatocytes. Environ Toxicol. 28, 401, 2013.

17. STAMATELOS S. K., BRINKERHOFF C. J., ISUKAPALLI S. S., GEORGOPOULOS P.G. Mathematical model of uptake and metabolism of arsenic(III) in human hepatocytes - Incorporation of cellular antioxidant response and threshold-dependent behavior. BMC Syst Biol. 5, 16, 2011.

18. LIU D., DUAN X., DONG D., BAI C., LI X., SUN G., LI B. Activation of the Nrf2 Pathway by Inorganic Arsenic in HumanHepatocytes and the Role of Transcriptional Repressor Bach1. Oxid Med Cell Longev 2013. doi: $10.1155 / 2013 / 984546$
19. WANG Q., LI Y., LI S., TIAN Q., HAN J. Experimental study of arsenic and the antagonistic action of vitam in $\mathrm{E}$ on lipid peroxidation in the organs ofm ic. Chin J Ctrl Endem Di. 24, (1), 9, 2009.

20. WANG Y.W., YANG K., TANG H., CHEN D., BAI Y.L. Toxicity assessment of repeated intravenous injections of arginine-glycine-aspartic acid peptide conjugated $\mathrm{CdSeTe} / \mathrm{ZnS}$ quantum dots in mice. Int J Nanomedicine. 10, (9), 4809, 2014.

21. KHAN B.I., SOLO-GABRIELE H. M., DUBEY B. K., TOWNSEND T. G., CAI Y. Arsenic Speciation of SolventExtracted Leachate from New and Weathered CCA-Treated Wood. Environ Sci Technol. 38, (17), 4527, 2004.

22. GOMEZ-RUBIO P., ROBERGE J., ARENDELL L., HARRIS R.B., O'ROURKE M.K., CHEN Z., CANTU-SOTO E., MEZA-MONTENEGRO M.M., BILLHEIMER D., LU Z., KLIMECKI W.T. Association between body mass index and arsenic methylation efficiency in adult women from southwest U.S. and northwest Mexico. Toxicol Appl Pharmacol. 252, (2), 176, 2011.

23. JIN Y., XI S., LI X., LU C., LI G., XU Y., QU C., NIU Y., SUN G. Arsenic speciation transported through the placenta from mother mice to their newborn pups. Environ Res. 101, 349, 2006.

24. SHAN X. Speciation analysis and bioavailability. Chinese Journal of Analysis Laboratory. 20, (6), 103, 2011.

25. KUMAR A., SINGH R.P., SINGH PK., AWASTHI S., CHAKRABARTY D., KUMAR TRIVEDI P., TRIPATHI R. D. Selenium ameliorates arsenic induced oxidative stress through modulation of antioxidant enzymes and thiols in rice. Ecotoxicology. 7, 2, 2014.

26. NAUJOKAS M. F., ANDERSON B., AHSAN H., APOSHIAN H. V., GRAZIANO J., THOMPSON C., SUK W. A. The Broad Scope of Health Effects from Chronic Arsenic Exposure: Update on a Worldwide Public Health Problem Environ Health Perspect. 121, (3), 295, 2013

27. CHEN Y., PARVEZ F., GAMBLE M. Arsenic Exposure at Low-to-Moderate Levels and Skin Lesions, Arsenic Metabolism, Neurological Functions, and Biomarkers for Respiratory and Cardiovascular Diseases: Review of Recent Findings from the Health Effects of Arsenic Longitudinal Study (HEALS) in Bangladesh. Toxicol Appl Pharmacol. 239, (2), 184, 2009.

28. LIU J., WAALKES M. P. Liver is a Target of Arsenic Carcinogenesis. Toxicol Sci. 105, (1), 24, 2008.

29. LI Z., HENNING S.M, ZHANG Y., ZERLIN A., LI L., GAO K., LEE R.P., KARP H., THAMES G., BOWERMAN S., HEBER D. Antioxidant-rich spice added to hamburger meat during cooking results in reduced meat, plasma, and urine malondialdehydeconcentrations. Am J Clin Nutr. 91, (5), 1180, 2010.

30. LUBOS E., LOSCALZO J., HANDY D. E. Glutathione Peroxidase-1 in Health and Disease: From Molecular Mechanisms to Therapeutic Opportunities. Antioxid Redox Signal. 15, (7), 1957, 2011.

31. PERRY J.J.P., SHIN D.S., GETZOFF E.D., TAINER JA. The structural biochemistry of the superoxide dismutases. Biochim Biophys Acta. 1804, (2), 245, 2010.

32. QUINTANA-CABRERA R., FERNANDEZ-FERNANDEZ S., BOBO-JIMENEZ V., BOBO-JIMENEZ V., ESCOBAR J., SASTRE J., ALMEIDA A., BOLAÑOS J.P. $\gamma$ Glutamylcysteine detoxifies reactive oxygen species by acting as glutathione peroxidase-1 cofactor. Nat Commun. 2012. doi: $10.1038 /$ ncomms 1722 
33. KER Y.B., CHEN K.C., PENG C.C., HSIEH C.L, PENG R.Y. Structural Characteristics and Antioxidative Capability of the Soluble Polysaccharides Present in Dictyophora indusiata (Vent. Ex Pers.) Fish Phallaceae. Evid Based Complement Alternat Med. 2011. doi: 10.1093/ecam/neq041

34. POLJSAK B., MILISAV I. The Neglected Significance of "Antioxidative Stress". Oxid Med Cell Longev. 2012. doi: $10.1155 / 2012 / 480895$
35. HUGHES M. F., BECK B. D., CHEN Y., LEWIS A. S., THOMAS D. J. Arsenic Exposure and Toxicology: A Historical Perspective. Toxicol Sci. 123, (2), 305, 2011.

36. MARTINEZ V. D., VUCIC E. A., BECKER-SANTOS D. D., GIL L., LAM W. L. Arsenic Exposure and the Induction of Human Cancers. J Toxicol. 2011. doi:10.1155/2011/431287

37. THOMAS DJ, STYBLO M., LIN S. The cellular metabolism and systemic toxicity of arsenic. Toxicol Appl Pharmacol, 176, (2),127, 2011. 